\title{
Long-term cover crops in paddy field increase enzyme activity and carbon stock and enable the system fertilization
}

\author{
Filipe Carlos ${ }^{1}$, Rogerio Sousa ${ }^{2}$, Rafael Nunes ${ }^{3}$, Felipe Carmona ${ }^{4}$, Tiago Cereza ${ }^{3}$, Cristiano \\ Weinert $^{2}$, Cimelio Bayer ${ }^{5}$, and Flávio Camargo ${ }^{5}$ \\ ${ }^{1}$ Universidade Federal de Pelotas \\ ${ }^{2}$ Federal University of Pelotas \\ ${ }^{3}$ Rio Grande do Sul Rice Institute \\ ${ }^{4}$ Integrar Research Company \\ ${ }^{5}$ Federal University of Rio Grande do Sul
}

February 6, 2022

\begin{abstract}
The use of cover crops and the adoption of no-tillage are essential conservation practices to increase carbon and nitrogen stocks and increase soil microbial activity. However, in lowland areas cultivated with irrigated rice, there is a large gap on the effects of no-tillage with long-term cover crops on soil attributes, crop responses and the effect of the system fertilization. The aim of this work was to evaluate the long-term adoption of cover crops on soil microbial activity, soil carbon stock and on the response of irrigated rice to system fertilization. Treatments consisted of fallow-conventional, fallow-no tillage, Annual Ryegrass, Oat, Ornithphus micranthus and Lotus cornicultaus. In the sub-plots, system and conventional fertilization per crop were compared. The experiment was conducted in southern Brazil in an Entisol and started in the 1996/97 crop season. Cover crops associated with the use of no-tillage increases basal respiration $(+31 \%)$ of the soil, $\beta$-glucosidase activity $(+259 \%)$, and soil carbon and nitrogen stocks. Urease activity increased by an average of $41 \%$ in no-tillage under cover crops compared to the conventional system under fallow, with the exception of ryegrass. System fertilization promoted higher dry matter production $(+130 \%)$ in grasses and a lower increase $(+23 \%)$ in winter legumes. The use of long-term cover crops promoted higher rice productivity $(+9 \%)$. In this way, the association of cover crops and no-tillage increases carbon and nitrogen stocks, the biological activity of the soil and makes possible the system fertilization in lowlands, with positive effects on productivity.
\end{abstract}

Long-term cover crops in paddy field increase enzyme activity and carbon stock and enable the system fertilization

Filipe Selau Carlos ${ }^{1 *}$, Rogério Oliveira de Sousa ${ }^{1}$, Rafael Nunes ${ }^{2}$, Felipe de Campos Carmona ${ }^{3}$, Tiago Cereza $^{2}$, Cristiano Weinert ${ }^{1}$, Cimélio Bayer ${ }^{4}$, Flávio Anastácio de Oliveira Camargo ${ }^{4}$.

${ }^{1}$ Federal University of Pelotas, Av. Eliseu Maciel s/n, Capão do Leão, Brazil.

${ }^{2}$ Rio Grande do Sul Rice Institute - IRGA, Cachoeirinha, Brazil.

${ }^{3}$ Integrar Research Company, Capivari do Sul, Brazil.

${ }^{4}$ Federal University of Rio Grande do Sul, Porto Alegre, Brazil.

*Corresponding author, filipeselaucarlos@hotmail.com

Abstract 
The use of cover crops and the adoption of no-tillage are essential conservation practices to increase carbon and nitrogen stocks and increase soil microbial activity. However, in lowland areas cultivated with irrigated rice, there is a large gap on the effects of no-tillage with long-term cover crops on soil attributes, crop responses and the effect of the system fertilization. The aim of this work was to evaluate the long-term adoption of cover crops on soil microbial activity, soil carbon stock and on the response of irrigated rice to system fertilization. Treatments consisted of fallow-conventional, fallow-no tillage, Annual Ryegrass, Oat, Ornithphus micranthus andLotus cornicultaus. In the sub-plots, system and conventional fertilization per crop were compared. The experiment was conducted in southern Brazil in an Entisol and started in the $1996 / 97$ crop season. Cover crops associated with the use of no-tillage increases basal respiration $(+31 \%)$ of the soil, $\beta$-glucosidase activity $(+259 \%)$, and soil carbon and nitrogen stocks. Urease activity increased by an average of $41 \%$ in no-tillage under cover crops compared to the conventional system under fallow, with the exception of ryegrass. System fertilization promoted higher dry matter production $(+130 \%)$ in grasses and a lower increase $(+23 \%)$ in winter legumes. The use of long-term cover crops promoted higher rice productivity $(+9 \%)$. In this way, the association of cover crops and no-tillage increases carbon and nitrogen stocks, the biological activity of the soil and makes possible the system fertilization in lowlands, with positive effects on productivity.

Keywords : lowlands, microbial activity, conservation management, Oryza sativa, soil quality.

\section{Introduction}

The use of cover crops is a conservation practice that enables the improvement of soil quality (Carlos et al., 2022, 2021; Martins et al., 2017), especially in subtropical conditions such as Southern Brazil (Balota et al., 2014). Numerous benefits have arisen from the use of cover crops, such as reduced soil erosion (De Baets et al., 2011), less nitrate leaching (Alvarez et al., 2017) and increased nutrient availability in the cash crop development period (Carlos et al., 2020; O'Connell et al., 2015). The use of cover crops promotes increased levels of organic carbon in the soil (Denardin et al., 2019), which is one of the principles for maintaining the sustainability of agriculture (Bayer et al., 2004). The increase in carbon contents is related to the physical, chemical and biological quality of the soil, as well as the mitigation of global warming. These happen through the sequestration of $\mathrm{C}-\mathrm{CO}_{2}$ from the atmosphere with the adoption of cover crops associated with no-tillage in many places in the world (Congreves et al., 2017; Dossou-Yovo et al., 2016; Sousa et al., 2021) and in sub-tropical conditions (Assmann et al., 2014; Bayer et al., 2002; Martins et al., 2017).

Cover crops provide a rapid source of energy and nutrients to the soil microbiota, contributing to increased basal respiration (Carlos et al., 2021) and the activity of extracellular soil enzymes (Carlos et al., 2020; Martins et al., 2017). The soil microbiota, in turn, is of great importance in the cycling of nutrients in the soil (Burns et al., 2013) and reduction of nutrient losses in the intercrop period (Alvarez et al., 2017). However, there is a large scientific gap on the effects of long-term cover crops on lowland soil attributes and on irrigated rice grain productivity (Carlos et al., 2021, 2020). The lower adoption of cover crops in lowland is due to unfavorable chemical and physical soil attributes, especially low porosity and poor drainage, which result in lower oxygen availability, hindering the development and affecting plant yield (Martins et al., 2017). In addition to aspects related to the physical attributes of the soil, chemically lowland soils have low OM contents, low CEC (Boeni et al., 2010) and sum of bases and also low levels of phosphorus (Cardoso et al., 2020). These chemical and physical limitations reduce the options for cover crop species adapted to lowland cultivation, when compared to the options available for upland soils, in addition to requiring investments in drainage and fertilization to enable the cultivation (Menezes et al., 2001).

In Brazil, recently, a new method of fertilization has been studied, called system fertilization. The recommendations in system fertilization consider the nutritional requirements of the crops established in a production system instead of the fertilization that considers only the requirements of the isolated crop, which is the most used fertilization management. The management of system fertilization has some requirements such as the use of cover crops and direct planting that promote nutrient cycling and minimize loss processes. The application of nutrients required by commercial crops is carried out in cover crops, where there is no nutrient export by the grains. When there is an integration between crop and livestock, fertilization is carried out in 
forage, which, as they are subject to grazing, export a low amount of nutrients (Carlos et al., 2020). This system considers the carry-over of nutrients applied to cover crops and forage that will be made available to commercial crops. The concept of system fertilization can minimize the chemical limitations presented by lowland soils to the cultivation of cover crops. The rice used in the sequence can benefit from the greater cycling of nutrients due to the increase in microbial activity resulting from the contribution to the soil of residues from cover crops. Thus, cover crops have immediate effects on energy and nutrient fluxes, microbial activity and soil carbon stocks, consequently, they can affect the availability of nutrients and the development and productivity of agricultural crops (Alvarez et al., 2017). In studies carried out evaluating the cultivation of maize in succession to ground covers, the vast majority of grain productivity were similar or higher in the presence of cover crops (Miguez and Bollero, 2005; O'Reilly et al., 2012). However, yield is related to the species of cover crop (grass or legume) and climatic conditions, being considered as preponderant factors for the successful use of cover crops (Alvarez et al., 2017). In the production of irrigated rice, the related information is still inconsistent.

In irrigated rice production, information related to the contribution of leguminous and grass cover under no-tillage and their contributions to soil microbiota activity, carbon and nitrogen stocks, and rice yield under no-tillage and system fertilization is still inconsistent.

Thus, this work aims to evaluate soil microbial activity, carbon and nitrogen contents and stocks, and the response of cover crops and irrigated rice under long-term fertilization in a no-tillage system in Southern Brazil.

\section{Material and methods}

\subsection{Site Description}

The long-term experiment was installed in the 1996/97 crop season at the Rice Experimental Station of the Instituto Rio Grandense do Arroz, State of Rio Grande do Sul, Southern Brazil, 2955'30" S and 5058'21" $\mathrm{W}$ and $7 \mathrm{~m}$ of altitude (Figure 1). The Soil of the experiment was classified as Entisol (Endoaquent) (US Soil Taxonomy, 1999). In the implementation of the experimental protocol, its characteristics in the $0-20 \mathrm{~cm}$ layer were: $140 \mathrm{~g} \mathrm{~kg}^{-1}$ of clay; $16 \mathrm{~g} \mathrm{~kg}^{-1}$ of organic matter; $9.8 \mathrm{mg} \mathrm{kg}-1 \mathrm{P} ; 25 \mathrm{mg} \mathrm{kg}-1 \mathrm{~K} ; 1.2 \mathrm{cmol} \mathrm{kg}^{-1} \mathrm{Ca}^{-2}$ and $0.4 \mathrm{cmol} \mathrm{kg}^{-1} \mathrm{Mg}$. Prior to the establishment of the experiment, the area was cultivated with irrigated rice under conventional tillage and fallow in the winter period. In the 2013/14 crop season, soybean (Glycine max ) was uniformly cultivated in the experiment to reduce the incidence of weeds, mainly red rice (Oryza sativa L.). The average temperature of the coldest month (June) is $14.3^{\circ} \mathrm{C}$, that of the hottest month (January) is $25.2{ }^{\circ} \mathrm{C}$ and the annual average is $19.6^{\circ} \mathrm{C}$. The local climate is humid subtropical according to Köppen with an average annual precipitation of $1,398 \mathrm{~mm}$.

\subsection{Experimental Design}

The experimental design used was randomized blocks with three replications. In the main plot, the soil covers were placed, being distributed in 6 treatments, fallow-conventional, fallow-no tillage, Annual Ryegrass (Lolium multiflorum ), black oats (Avena strigosa), Ornithphus micranthus and Lotus cornicultaus, being the first two species grasses (Poaceae ) and the last two legumes. From the 2012/13 crop season, the plots were subdivided into sub-plots comprising the fertilization treatments: system fertilization and conventional fertilization per crop. The experimental units consisted of plots $5 \mathrm{~m}$ wide and $8.75 \mathrm{~m}$ long, totaling an area of $43.75 \mathrm{~m}^{2}$.

The rice crop was established directly on the desiccated covers by applying full action herbicide, around 30 days before sowing. The annual fertilization from the 1996/97 crop season to the 2012/13 crop season corresponded on average to $135 \mathrm{~kg} \mathrm{ha}^{-1}$ of $\mathrm{N}, 60 \mathrm{~kg} \mathrm{ha}^{-1}$ of $\mathrm{P}_{2} \mathrm{O}_{5}$ and $90 \mathrm{~kg} \mathrm{ha}^{-1}$ of $\mathrm{K}_{2} \mathrm{O}$. Fertilization of $\mathrm{P}$ and $\mathrm{K}$ was applied at sowing and fractioned $\mathrm{N}$ was applied $66 \%$ at the phenological stage $\mathrm{V} 3-\mathrm{V} 4$ and 
the remainder at panicle primordia differentiation (R0) (Counce et al., 2000). In the 2012/13, 2014/15 and $2015 / 16$ crop seasons, half of the useful area $22 \mathrm{~m}^{2}$; the system fertilization was carried out, which consisted in the application of all the rice fertilization needs, 150-68-108 $\left(\mathrm{N}_{-} \mathrm{P}_{2} \mathrm{O}_{5}-\mathrm{K}_{2} \mathrm{O}\right)$ in the cover crops. In the other half of the plot, conventional fertilization was carried out, where all the nutrient demand was applied directly at sowing time $\left(\mathrm{P}_{2} \mathrm{O}_{5}\right.$ and $\left.\mathrm{K}_{2} \mathrm{O}\right)$ and during development $(\mathrm{N})$ of the rice crop. The management of weeds and pest insects has always been performed as recommended by researchers for high yield of irrigated rice (SOSBAI, 2018).

\subsection{Sampling and analyses}

\subsubsection{Basal respiration}

For analysis of basal respiration and extracellular enzyme activity, soil samples were collected after the winter cycle in September 2015. Six sub-samples were taken at 0-0.05 m with the aid of an auger in the sub-plot that received conventional fertilization. After collection, the samples were sieved $(5 \mathrm{~mm})$ and later sent for incubation. The basal respiration was evaluated by the incubation method and estimated from the amount of $\mathrm{CO}_{2}$ released after 61 days. Soil samples under $70 \%$ field capacity were incubated at $25 \mathrm{oC}$ in airtight flasks containing $\mathrm{NaOH}$ to capture the $\mathrm{CO}_{2}$ enveloped from microbial respiration. The $\mathrm{CO}_{2}$ was quantified by titrating the residual $\mathrm{NaOH}$ with $\mathrm{HCl}$ (Stotzky, 1972).

\subsubsection{Extracellular enzyme (EE) activity}

After collection, the samples were sieved $(5 \mathrm{~mm})$ and subsequently refrigerated $(<5 \mathrm{degC})$ for a period of less than 7 days, until the moment of the enzymatic analysis. The $\beta$-glucosidase activity was determined using p-nitrophenyl- $\beta$-glucopyranoside as substrate and incubated for one hour with $1 \mathrm{~g}$ of soil sample in a buffer $\mathrm{pH} 6.0$, at $37^{\circ} \mathrm{C}$. This buffer was composed of tris $\left(12,200 \mathrm{mg} \mathrm{L}^{-1}\right)$, maleic acid $\left(11,600 \mathrm{mg} \mathrm{L}^{-1}\right)$, citric acid $\left(14,000 \mathrm{mg} \mathrm{L}^{-1}\right)$ and boric acid $\left(6,300 \mathrm{mg} \mathrm{L}^{-1}\right)$ mixed with $488 \mathrm{~mL} \mathrm{NaOH} 1 \mathrm{M}$. After the incubation, $1 \mathrm{~mL}$ of, $0.5 \mathrm{~mol} \mathrm{~L}^{-1} \mathrm{CaCl}_{2}$ were added. The Tris solution ( $\mathrm{pH}$ 12.0) was added to precipitate humic molecules responsible for the brown color extract and p-nitrophenol. The p-nitrophenol generated from the reaction in the soil was colorimetrically measured at $410 \mathrm{~nm}$ (Tabatabai, 1982). A negative control for each EEs activity assay was used, following the same procedures described above, but without the soil sample addition. To determine urease activity, $5.0 \mathrm{~g}$ of each soil sample were transferred to a $50 \mathrm{~mL}$ tube containing $9 \mathrm{~mL}$ of Tris Hydroxymethyl Amino Methane (THAM) Buffer, and 2,5 mL of $0.2 \mathrm{~mol} \mathrm{~L}^{-1}$ Urea $\left(\mathrm{CH}_{4} \mathrm{~N}_{2} \mathrm{O}\right)$ solution were added and, immediatly, the tubes were incubated at $37^{\circ} \mathrm{C}$ for two hours. After the incubation, $35 \mathrm{~mL}$ of 2,5 mol L-1 Potassium Chloride $(\mathrm{KCl})$ and Silver Sulfate $\left(\mathrm{Ag}_{2} \mathrm{SO}_{4}\right)\left(100 \mathrm{mg} \mathrm{L}^{-1}\right)$ solution at $4^{\circ} \mathrm{C}$ were added to the each tube until complete the total volume of $50 \mathrm{~mL}$. Microdestilation was used to determine the Ammonium $\left(\mathrm{NH}_{4}{ }^{+}\right)$generated by the action of urease to urea (Tedesco et al., 1995). For Fluorescein DiAcetate (FDA) hydrolysis determination $2 \mathrm{~g}$ of soil were transferred to two volumetric flasks where 15 $\mathrm{mL}$ of phosphate buffer and in one of them $0.2 \mathrm{~mL}$ of FDA was added. The flasks were incubated at $30^{\circ} \mathrm{C}$, under agitation for $30 \mathrm{~min}$. Subsequently, $15 \mathrm{~mL}$ of a 2:1 mixture of chloroform / methanol, respectively. The samples were centrifuged at $2000 \mathrm{rpm}$ for $3 \mathrm{~min}$. The color intensity of the supernatant was determined by spectrophotometer at $490 \mathrm{~nm}$ (Adam and Duncan, 2001)(Adam and Duncan, 2001).

\subsubsection{Total contents and stocks of carbon and nitrogen in the soil}

The soil was sampled in September 2015 using a cutting shovel, 18 years after the experiment was installed, September 1996. The $\mathrm{C}$ and $\mathrm{N}$ contents were analyzed in eight layers of soil: 0 to $2.5 ; 2.5$ to $5 ; 5$ to 7.5 ; $7.5-10 ; 10$ to $15 ; 15$ to $20 ; 20$ to 30 , and 30 to $40 \mathrm{~cm}$. The soil samples resulted in four sub-samples per experimental plot in all field repetitions. The soil was dried $\left(45^{\circ} \mathrm{C}\right)$ and sieved through a $2 \mathrm{~mm}$ mesh for analysis. In order to calculate the stocks, soil density was determined using volumetric rings, measuring 160 $\mathrm{cm}^{3}$. Subsequently, the soil samples were milled in agate grade and sent to the determination of the total carbon and nitrogen contents in a Shimadzu elemental analyzer. To estimate the stocks, soil density values in the 0-0.2 and 0.2-0.4 $\mathrm{m}$ layers were used.

\subsubsection{Cover crops dry matter}


To determine the dry matter production of cover crops, samples were collected in an area of $0.25 \mathrm{~m}^{2}$ throughout the development cycle in the subplots with conventional and system fertilization. Afterwards, the samples were sent to the laboratory and dried in ovens with air circulation $(45 \mathrm{oC})$ until reaching constant weight. Subsequently, the material was weighed, ground $(2 \mathrm{~mm})$, and acid digested for further determination of the accumulated amounts of nitrogen, phosphorus and potassium (Tedesco et al., 1995). To determine the addition of carbon by the roots, 1 soil monolith per experimental unit was collected in the dimensions of 0.2 x $0.2 \times 0.2 \mathrm{~m}$ and then the roots were washed with running water and a sieve. To calculate the addition of carbon by roots and shoots, the amount of dry matter was used and the mean factor of carbon concentration in dry matter of $45 \%$ was used (Assmann et al., 2014).

\subsubsection{Rice productivity}

To determine the grain productivity, two areas of $4 \mathrm{~m}$ long and 7 rows of plants $(1.19 \mathrm{~m})$ were sampled in each plot, totaling $4.76 \mathrm{~m}^{2}$. Afterwards, the samples were threshed, removed the impurities, determined weight and humidity. All grain samples were adjusted to $13 \%$ moisture.

\subsection{Statistical analysis}

The Shapiro-Wilk test was used to test the normality of the data. Basal respiration data were subjected to regression and difference by the $95 \%$ confidence interval. Dataset on enzymatic activity, carbon and nitrogen contents and stocks, and rice grain productivity were subjected to ANOVA according to the experimental design. Statistical analysis was applied to each of the parameters studied. When the F-test was significant $(\mathrm{p}<0.05)$, the parameters were compared using Tukey's test $(\alpha=0.05)$. Pearson's correlation coefficients were calculated for all chemical and microbiological attributes of the soil, dry matter of cover crops and rice grain productivity.

Additionally, to evaluate changes in environmental variables (soil properties induced by cover crops) and rice grain productivity were subjected to a principal component analysis (PCA). The entire dataset consisted of carbon and nitrogen stock values, basal respiration, soil enzyme activity, carbon addition by cover crops, and rice grain productivity. In the ordination plots presented, the vectors indicated the relative importance of soil properties and grain productivity, explaining the variability between cover crops and use of system fertilization. For PCA analysis, the R statistical software was used.

\section{Results}

\section{Basal repiration}

No-tillage, regardless of the type of coverage, provided the highest values of basal respiration compared to the fallow-CT (Figure 2). In the fallow-CT treatment, the accumulated basal respiration was $361 \mathrm{mg} \mathrm{CO}_{2} \mathrm{~kg}$ soil $^{-1}$, while in the treatments under no-tillage it ranged on average from 411 to $476 \mathrm{mg} \mathrm{CO} \mathrm{kg} \mathrm{soil}^{-1}$. Under no-tillage, Ornithopus (486 mg $\mathrm{CO}_{2} \mathrm{~kg} \mathrm{soil}^{-1}$ ) stood out as the cover crop with the highest accumulated basal respiration.

Enzymatic activity

No-tillage, regardless of whether they were associated with cover crops or fallow, was observed to increase $\beta$-glucosidase activity (Figure 3). Under fallow-CT, $\beta$-glucosidase activity was $26 \mu \mathrm{g} \mathrm{PNP} \mathrm{g} \mathrm{g}^{-1} \mathrm{~h}^{-1}$, whereas with the adoption of no-tillage it was in the range of 81 to $113 \mu \mathrm{g}$ PNP g ${ }^{-1} \mathrm{~h}^{-1}$, which meant an increase average of $252 \%$ in the activity of this enzyme. The treatments under no-tillage showed urease activity higher than fallow-CT, except for Ryegrass. The mean urease activity in treatments with cover crops, with the exception of Ryegrass, was $32 \mathrm{mg} \mathrm{NH}_{4}{ }^{+} \mathrm{g}^{-1} \mathrm{~h}^{-1}$. The treatments with Ryegrass and fallow-CT showed activity of 21 and $22 \mathrm{mg} \mathrm{NH}{ }_{4}^{+} \mathrm{g}^{-1} \mathrm{~h}^{-1}$, respectively (Figure 3). The fluorescein diacetate activity was not significantly influenced by treatments (Figure 3 ).

Soil carbon and nitrogen contents and stocks 
The long-term cultivation of cover crops influenced the levels of carbon and nitrogen in the soil (Figure 4) and consequently the stocks of these elements, mainly in the superficial layer (Figure 5). The fallow-CT was the treatment that had the lowest $\mathrm{C}$ and $\mathrm{N}$ contents on the surface and in the fallow-NT there was intermediate contents between the fallow-CT and the cover crops that presented the highest $\mathrm{C}$ and $\mathrm{N}$ contents on the surface $(0-5 \mathrm{~cm})$. Ornithopus and Oat were the cultures that showed the highest surface carbon content (Figure 4) and consequently the highest carbon stock (Figure 5). Regarding nitrogen, the highest levels of nitrogen in the soil profile were observed (Figure 4) and the largest stock with Ornithopus (Figure 5). On the other hand, lower surface nitrogen contents $(0-5 \mathrm{~cm})$ were observed under oat and Lotus crops compared to Ornithopus (Figure 4). The fallow-CT was the treatment that presented the lowest nitrogen stocks in the soil (Figure 4).

Dry matter and accumulation of nitrogen, phosphorus and potassium in cover crops

It was observed that the system fertilization provided a $97 \%$ increase in oat dry matter production, reaching 7.6 $\mathrm{Mg} \mathrm{ha}^{-1}$ at the end of the cycle with an accumulation of 128,28 and $226 \mathrm{~kg} \mathrm{ha}^{-1}$ of $\mathrm{N}, \mathrm{P}$ and K, respectively (Figure 6). The system fertilization had a dry matter production of $7.0 \mathrm{Mg} \mathrm{ha}^{-1}(+163 \%)$ of Ryegrass and accumulations of 130, 29 and $196 \mathrm{~kg} \mathrm{ha}^{-1}$ of N, P and K, respectively (Figure 7). While conventional fertilization showed a production of $2.6 \mathrm{Mg} \mathrm{ha}^{-1}$ and accumulation of 30,9 and $48 \mathrm{~kg} \mathrm{ha}^{-1}$ of N, P and K in the dry matter of Ryegrass (Figure 7). Ornithopus and Lotus also had an influence of system fertilization on dry matter production and nutrient accumulation, however, these legumes had a lower magnitude of system fertilization than grasses. Under system fertilization, Ornithopus showed dry matter production of $4.7 \mathrm{Mg} \mathrm{ha}^{-1}(+9 \%)$ and accumulation of 132, 13 and $71 \mathrm{~kg} \mathrm{ha}^{-1}$ of $\mathrm{N}, \mathrm{P}$ and $\mathrm{K}$ (Figure 8). Under conventional fertilization the dry matter production of Ornithopus was $4.3 \mathrm{Mg} \mathrm{ha}^{-1}$ and accumulation of 126, 13 and $70 \mathrm{~kg} \mathrm{ha}^{-1}$ of N, P and K, respectively (Figure 8). In Lotus under system fertilization it was observed a dry matter production of $3.4 \mathrm{Mg} \mathrm{ha}^{-1}(+38 \%)$ and accumulated of 136,31 and $113 \mathrm{~kg} \mathrm{ha}^{-1}$ of N, $\mathrm{P}$ and $\mathrm{K}$ (Figure 9). Lotus under conventional fertilization showed a dry matter production of $2.5 \mathrm{Mg} \mathrm{ha}^{-1}$ and accumulated contents of 119, 14 and $96 \mathrm{~kg} \mathrm{ha}^{-1}$ of N, P and K, respectively (Figure 9).

\section{Rice Grain Productivity}

Regarding the response of the irrigated rice crop to fertilization, when conventional fertilization was performed, the grain productivity was $8.9 \mathrm{Mg} \mathrm{ha}^{-1}$, representing $27 \%$ higher than the system fertilization (7.0 $\mathrm{Mg} \mathrm{ha} \mathrm{a}^{-1}$ ), on the average of the three crop seasons evaluated (2012/13, 2014/15 and 2015/16) (Figure 10). When the conventional fertilization in two crop seasons was evaluated in isolation, lower grain productivity was observed in the treatments when ryegrass and fallow-CT were adopted in the winter (Figure 10). The ryegrass and fallow-CT treatments had productivity 3 and $8 \%$ lower under conventional fertilization than the average of the other treatments in the three crop seasons evaluated, respectively (Figure 10). When the system was fertilized, fallow-CT and fallow NT had lower productivity in two crop seasons compared to the other treatments (Figure 10). On the average of the three crop seasons, rice grain productivity using cover crops and system fertilization was 11 and $8 \%$ higher than fallow-NT and fallow-CT, respectively (Figure 10).

Pearson correlation and principal component analysis

In the Perason correlation, a high degree of relationship between carbon and nitrogen stocks was observed (Figure 11). Carbon and nitrogen stocks also showed a high degree of association with the addition of carbon by cover crop roots (Figure 11). Basal respiration and $\beta$-glucosidase and urease activities showed positive relationships with soil carbon and nitrogen stocks (Figure 11). Rice grain productivity under system and conventional fertilization showed a positive relationship with carbon and nitrogen stocks and with carbon added by the roots of cover crops (Figure 11).

Regarding the analysis of principal components, it was observed that $44.5 \%$ of the variations were due to PC1 (Figure 12). On the other hand, PC2 was responsible for $18 \%$ of the observed variation (Figure 12). It was observed that none of the analyzed variables converged to the fallow-CT treatment. On the other hand, there was a conversion of indicators of carbon and nitrogen stocks, grain productivity, soil enzyme activities and basal respiration for treatments using soil covers and under no-tillage (Figure 12). FDA activity and 
shoot carbon were the only variables that did not converge to the cover crop clusters under NT.

\section{Discussion}

\section{Enzyme activity and basal respiration}

The use of cover crops influences the activity of soil enzymes and basal respiration (Carlos et al., 2020). The greater addition of plant residues in the autumn-winter period by shoots, roots and exudates contributes to the increase in labile carbon in the soil, which is the main source of energy and nutrients for the soil microbiota (Carlos et al., 2021; Martins et al., 2017). Cover crops act mainly with the input of residues throughout the cycle through the senescence of leaves, rhizodeposition, and plant residues, leaves and roots at the end of the cycle (Mcdaniel and Grandy, 2016). The $\beta$-glucosidase activity is closely related to the degradation of carbon-rich compounds, mainly cellulose, hemicellulose, glucose and other compounds (Tenelli et al., 2019). Urease, on the other hand, is related to the mineralization of ammonium labile plant residues (Fei et al., 2020). In general, studies investigating the adoption of lowland cover crops traditionally cultivated with irrigated rice are scarce (Carlos et al., 2020). This condition occurs mainly due to the frequent occurrence of excess water, which reduces the availability of oxygen in these soils and affects the development of cover crops. However, some studies regarding Southern Brazil lowlands verified the adoption of ryegrass and Persian clover in lowlands in the autumn winter period under grazing with cattle (under integrated livestock farming) increased the activity of $\beta$-glucosidase and urease (Carlos et al., 2020). Some authors have associated the root volume of cover crops as responsible for the increase in the activity of soil enzymes (Martins et al., 2017). Some authors observed that management changes are already reflected in the short term in the increase of soil microbial activity due to lowland soils in southern Brazil, as they are mostly sedimentary with a sandy texture and low organic carbon content (Carlos et al., 2022).

\subsection{Carbon and nitrogen stocks}

The higher activity of the soil microbiota is related to the larger microbial biomass that contributes to the greater development of filamentous fungi that increase soil aggregation (Balota et al., 2014; Burns et al., 2013; Mcdaniel and Grandy, 2016). Soil aggregation is one of the main mechanisms of occlusion and retention of organic forms in the soil (Abiven et al., 2009; Alvarez et al., 2017). Organic compounds are often protected from the action of the enzymatic complex of microorganisms in these soil structures (Burns et al., 2013) by reducing carbon oxidation and increasing carbon and nitrogen contents in the soil. In this sense, the associated adoption of cover crops and no-tillage are fundamental practices for increasing soil microbiological activity and increasing $\mathrm{C}$ and $\mathrm{N}$ stocks (Sousa et al., 2021). Although little practiced in much of the area cultivated with rice in Brazil $(<5 \%)$ (Sousa et al., 2021) other recent works demonstrate that no-tillage in environments cultivated with rice can contribute to the increase of carbon stock, mainly in the topsoil (Denardin et al., 2019). In that same experimental station, in a 20-year experiment under NT, it was also verified that no-tillage was important for the increase of enzymes such as $\beta$-glucosidase and urease, being mainly attributed to the increase in labile carbon fractions (Carlos et al., 2021). In South America, in the fall-winter period, many paddy fields are fallowed in the fall-winter period, contributing to a low addition of carbon to the soil (2-3 $\mathrm{Mg} \mathrm{C} \mathrm{ha}^{-1} \mathrm{yr}^{-1}$ ) (Alvarez et al., 2017). The effects of this low carbon input contribute to physical (Abiven et al., 2009), chemical (Denardin et al., 2019) and microbiological (Carlos et al., 2021) deterioration. In designing sustainable production systems, the positive carbon balance is essential (Bayer et al., 2000). Thus, the planning of crops that have a high contribution of carbon to the soil is essential to maintain the quality of soil organic matter (Martins et al., 2017).

\subsection{System fertilization in the development of cover crops and irrigated rice}

System fertilization had a relevant impact on the greater growth of cover crops, due to the low availability of phosphorus and potassium in the soil. In this fertilizer management strategy, there is a positioning of the $\mathrm{N}, \mathrm{P}$ and $\mathrm{K}$ requirement of irrigated rice in winter, which favors the development of cover crops, mainly ryegrass and oat. Legume species such as lotus and ornithopus, which have a high biological nitrogen fixation capacity, are less dependent on nitrogen supply. In addition, legumes are more sensitive to stress caused by 
excess water, which limits the production of green mass and the demand for nutrients. In general, to obtain a high level of productivity in irrigated rice $\left(10 \mathrm{Mg} \mathrm{ha}^{-1}\right), 150,30$ and $100 \mathrm{~kg} \mathrm{ha}^{-1}$ of $\mathrm{N}, \mathrm{P}$ and $\mathrm{K}$ fertilization, respectively, is recommended (SOSBAI, 2018). In system fertilization, the accumulated amounts of nitrogen at the end of the cover crop cycle were equivalent to 85 to $90 \%$ of the recommended amount for rice and 44 to $102 \%$ of the recommended amount of phosphorus. Under system fertilization there was an average accumulation of potassium at the end of the cover crop cycle of $211 \%$ and $78 \%$ of the recommended amount of the nutrient for rice, in grasses and legumes, respectively. When conventional fertilization was performed, the accumulated $\mathrm{N}$ in cover crops at the end of the cycle was $38 \%$ and $81 \%$ of rice crop demand in grasses and legumes, respectively. Under conventional fertilization there was also an average accumulation at the end of the cycle of cover crops of $63 \%$ of and $83 \%$ of $\mathrm{P}$ and $\mathrm{K}$, respectively. The system fertilization allowed an increase in nitrogen accumulation, mainly in grasses, due to the fact that they do not have a specialized apparatus in the symbiotic nitrogen fixation process, as observed in lotus and ornithopus. In relation to phosphorus, the system fertilization had the least influence on the development of cover crops. Possibly because the $\mathrm{P}$ content in the soil partially meets the need for cover crops. Finally, system fertilization practically doubled the amount of accumulated potassium, mainly due to the low availability of potassium in soils traditionally cultivated with rice such as the one in the present study.

However, the nitrogen and phosphorus present in plant residues from cover crops need to undergo mineralization processes to be made available to subsequent rice. Therefore, the supply of these quantities to the rice crop should not be considered in full. A fraction between 50 to $80 \%$ of nitrogen and phosphorus can be considered for crops in succession, due to the mineralization rate (Assmann et al., 2017) and the loss processes that occur in the soil, especially with nitrogen (Buchen et al., 2016; Cantarella et al., 2008). Thus, the improvement of microbial attributes and the increase in $\mathrm{C}$ and $\mathrm{N}$ stocks is directly related to the improvement in fertility and nutrient supply, which have an impact on the higher yield of irrigated rice in succession to cover crops.

However, when system fertilization is performed, on average, the productivity is lower than conventional fertilization. The rate of nutrient release by mineralization and the loss processes, mainly for nitrogen, are factors that are possibly associated with lower nutrition and grain productivity since nitrogen is the most limiting element to the development and rice grain productivity in the South of Brazil (Carlos et al., 2020). Possibly the inclusion of only $\mathrm{P}$ and $\mathrm{K}$ in studies of system fertilization is relevant so that there is no loss of productivity and grains in the rice crop.

Higher rice grain productivity in treatments under cover crops may be related to increased soil microbiological activity (Carlos et al., 2020; Martins et al., 2017) and nutrient cycling (Junjie Liu et al., 2015). Some authors have reported that the use of cover crops reduces losses due to nitrogen leaching into the soil, by an average of $70 \%$ when using grasses and 20\% when using legumes (Dabney et al., 2010). Other works also demonstrate the ability of cover crops to increase $\mathrm{P}$ retention in the soil and make it available to main crops (Jian Liu et al., 2015).

In general, the adoption of ground cover crops is an important step towards improving soil quality, mainly due to the increase in soil carbon stocks and the increase in microbial activity. This is an important premise for the adoption of system fertilization. However, as a reduction in the irrigated rice grain productivity with system fertilization was observed, future research suggests the anticipation of fertilization only with phosphorus and potassium, as they are less prone to losses. As for nitrogen, the maintenance of conventional fertilization is recommended, carried out throughout the development of the irrigated rice crop. As much as the soil is biologically more active, full anticipation of nitrogen in cover crops can provide loss processes such as volatilization, denitrification, leaching and even immobilization, limiting the supply of nitrogen in periods of high demand for irrigated rice.

Under the applied perspective, this work can also provide a fertilization alternative to maintain high levels of grain productivity and reduce fertilization levels through the use of cover crops, especially considering the high cost of fertilization and the potential impacts excess nitrogen and phosphorus in the environment (Signor et al., 2013). 


\section{Conclusions}

The adoption of long-term cover crops in lowland areas interspersed with irrigated rice cultivation under no-tillage increases microbial activity and soil carbon and nitrogen stocks in the topsoil.

System fertilization promotes greater development of cover crops and the accumulation of nitrogen, phosphorus and potassium, specially in the case of grasses when compared to legumes. In the long term, this management of fertilization can enhance the improvement of soil quality. The long-term use of cover crops promotes higher rice yield, especially when used system fertilization.

Thus, this work demonstrates the importance of adopting cover crops to improve soil microbial attributes of carbon and nitrogen stocks, which is essential for system fertilization. However, the use of this practice is still very incipient in the traditional areas of irrigated rice cultivation in Brazil. Future studies should still contemplate the positioning of phosphorus and potassium in the system fertilization and nitrogen must be applied conventionally in the development of irrigated rice crop, given the large number of loss processes of this nutrient.

\section{Acknowledgments}

The authors gratefully acknowledge all students and staff for teir contributios in the development of this research. The work was supported by Rio Grande do Sul Rice Institute (IRGA).

\section{Conflict of interest}

The authors declare that they have no conflict of interest.

\section{References}

Abiven, S., Menasseri, S., Chenu, C., 2009. The effects of organic inputs over time on soil aggregate stability - A literature analysis. Soil Biol. Biochem. 41, 1-12. https://doi.org/10.1016/j.soilbio.2008.09.015

Adam, G., Duncan, H., 2001. Development of a sensitive and rapid method for the measurement of total microbial activity using fluorescein diacetate (FDA) in a range of soils. Soil Biol. Biochem. 33, 943-951. https://doi.org/10.1016/S0038-0717(00)00244-3

Alvarez, R., Steinbach, H.S., De Paepe, J.L., 2017. Cover crop effects on soils and subsequent crops in the pampas: A meta-analysis. Soil Tillage Res. 170, 53-65. https://doi.org/10.1016/j.still.2017.03.005

Assmann, J.M., Anghinoni, I., Martins, A.P., Costa, S.E.V.G.D.A., Cecagno, D., Carlos, F.S., Carvalho, P.C.D.F., 2014. Soil carbon and nitrogen stocks and fractions in a long-term integrated crop-livestock system under no-tillage in southern Brazil. Agric. Ecosyst. Environ. 190. https://doi.org/10.1016/j.agee.2013.12.003

Assmann, J.M., Martins, A.P., Anghinoni, I., de Oliveira Denardin, L.G., de Holanda Nichel, G., de Andrade Costa, S.E.V.G., Pereira e Silva, R.A., Balerini, F., de Faccio Carvalho, P.C., Franzluebbers, A.J., 2017. Phosphorus and potassium cycling in a long-term no-till integrated soybean-beef cattle production system under different grazing intensities insubtropics. Nutr. Cycl. Agroecosystems 1-13. https://doi.org/10.1007/s10705-016-9818-6

Balota, E.L., Calegari, A., Nakatani, A.S., Coyne, M.S., 2014. Benefits of winter cover crops and no-tillage for microbial parameters in a Brazilian Oxisol: A long-term study. Agric. Ecosyst. Environ. 197, 31-40. https://doi.org/10.1016/j.agee.2014.07.010

Bayer, C., Martin-Neto, L., Mielniczuk, J., Ceretta, C.A., 2000. Effect of no-till cropping systems on soil organic matter in a sandy clay loam Acrisol from Southern Brazil monitored by electron spin resonance and nuclear magnetic resonance. Soil Tillage Res. 53, 95-104. https://doi.org/10.1016/S0167-1987(99)00088-4

Bayer, C., Martin-Neto, L., Mielniczuk, J., Pavinato, A., 2004. Armazenamento de carbono em frações lábeis da matéria orgânica de um Latossolo Vermelho sob plantio direto. Pesqui. Agropecuária Bras. 39, 677-683. 
https://doi.org/10.1590/S0100-204X2004000700009

Bayer, C., Mielniczuk, J., Martin-Neto, L., Ernani, P.R., 2002. Stocks and humification degree of organic matter fractions as affected by no-tillage on a subtropical soil. Plant Soil 238, 133-140. https://doi.org/10.1023/A:1014284329618

Boeni, M., Anghinoni, I., Genro Junior, S.A., Osório Filho, B.D., 2010. Evolução de fertilidade dos solos cultivados com arroz irrigado no Rio Grande do Sul. Porto Alegre.

Buchen, C., Lewicka-Szczebak, D., Fuß, R., Helfrich, M., Flessa, H., Well, R., 2016. Fluxes of N2 and $\mathrm{N} 2 \mathrm{O}$ and contributing processes in summer after grassland renewal and grassland conversion to maize cropping on a Plaggic Anthrosol and a Histic Gleysol. Soil Biol. Biochem. 101, 6-19. https://doi.org/10.1016/j.soilbio.2016.06.028

Burns, R.G., DeForest, J.L., Marxsen, J., Sinsabaugh, R.L., Stromberger, M.E., Wallenstein, M.D., Weintraub, M.N., Zoppini, A., 2013. Soil enzymes in a changing environment: Current knowledge and future directions. Soil Biol. Biochem. https://doi.org/10.1016/j.soilbio.2012.11.009

Cantarella, H., Trivelin, P.C.O., Contin, T.L.M., Dias, F.L.F., Rossetto, R., Marcelino, R., Coimbra, R.B., Quaggio, J.A., 2008. Ammonia volatilisation from urease inhibitor-treated urea applied to sugarcane trash blankets. Sci. Agric. 65, 397-401. https://doi.org/10.1590/S0103-90162008000400011

Cardoso, E.F., Wolter, R.C., Veçozzi, T.A., Teixeira, J.B.D.S., Carlos, F.S., Sousa, R.O., 2020. Phosphate fertilization for rice irrigated in soils with different phosphorus adsorption capacities. Arch. Agron. Soil Sci. https://doi.org/10.1080/03650340.2020.1827233

Carlos, F.S., Oliveira Denardin, L.G., Martins, A.P., Anghinoni, I., Faccio Carvalho, P.C., Rossi, I., Buchain, M.P., Cereza, T., Campos Carmona, F., Oliveira Camargo, F.A., 2020. Integrated crop-livestock systems in lowlands increase the availability of nutrients to irrigated rice. L. Degrad. Dev. 31, 2962-2972. https://doi.org/10.1002/ldr.3653

Carlos, F.S., Schaffer, N., Marcolin, E., Fernandes, R.S., Mariot, R., Mazzurana, M., Roesch, L.F.W., Levandoski, B., Oliveira Camargo, F.A., 2021. A long-term no-tillage system can increase enzymatic activity and maintain bacterial richness in paddy fields. L. Degrad. Dev. 32, 2257-2268. https://doi.org/10.1002/ldr.3896

Carlos, F.S., Schaffer, N., Mariot, R.F., Fernandes, R.S., Boechat, C.L., Roesch, L.F.W., Camargo, F.A. de O., 2022. Soybean crop incorporation in irrigated rice cultivation improves nitrogen availability, soil microbial diversity and activity, and growth of ryegrass. Appl. Soil Ecol. 170, 104313. https://doi.org/10.1016/J.APSOIL.2021.104313

Congreves, K.A., Hooker, D.C., Hayes, A., Verhallen, E.A., Van Eerd, L.L., 2017. Interaction of long-term nitrogen fertilizer application, crop rotation, and tillage system on soil carbon and nitrogen dynamics. Plant Soil 410, 113-127. https://doi.org/10.1007/s11104-016-2986-y

Counce, P.A., Keisling, T.C., Mitchell, A.J., 2000. A Uniform, Objective, and Adaptive System for Expressing Rice Development. Crop Sci. 40, 436-443.

Dabney, S.M., Delgado, J.A., Meisinger, J.J., Schomberg, H.H., Liebig, M.A., Kaspar, T., Mitchell, J., Reeves, W., 2010. Using Cover Crops and Cropping Systems for Nitrogen Management, in: IA, A. (Ed.), Advances in Nitrogen Management for Water Quality. pp. 230-281.

De Baets, S., Poesen, J., Meersmans, J., Serlet, L., 2011. Cover crops and their erosion-reducing effects during concentrated flow erosion. Catena 85, 237-244. https://doi.org/10.1016/j.catena.2011.01.009

Denardin, L.G. de O., Carmona, F. de C., Veloso, M.G., Martins, A.P., Freitas, T.F.S. d., Carlos, F.S., Marcolin, E., Camargo, F.A. de O., Anghinoni, I., 2019. No-tillage increases irrigated rice yield through soil quality improvement along time. Soil Tillage Res. 186, 64-69. https://doi.org/10.1016/j.still.2018.10.006 
Dossou-Yovo, E.R., Bruggemann, N., Ampofo, E., Igue, A.M., Jesse, N., Huat, J., Agbossou, E.K., 2016. Combining no-tillage, rice straw mulch and nitrogen fertilizer application to increase the soil carbon balance of upland rice field in northern Benin. Soil Tillage Res. 163, 152-159. https://doi.org/10.1016/j.still.2016.05.019

Fei, Y., Huang, S., Zhang, H., Tong, Y., Wen, D., Xia, X., Wang, H., Luo, Y., Barcelo, D., 2020. Response of soil enzyme activities and bacterial communities to the accumulation of microplastics in an acid cropped soil. Sci. Total Environ. 707, 135634. https://doi.org/10.1016/j.scitotenv.2019.135634

Liu, Jian, Bergkvist, G., Ulen, B., 2015. Biomass production and phosphorus retention by catch crops on clayey soils in southern and central Sweden. F. Crop. Res. 171, 130-137. https://doi.org/10.1016/j.fcr.2014.11.013

Liu, Junjie, Sui, Y., Yu, Z., Shi, Y., Chu, H., Jin, J., Liu, X., Wang, G., 2015. Soil carbon content drives the biogeographical distribution of fungal communities in the black soil zone of northeast China. Soil Biol. Biochem. 83, 29-39. https://doi.org/10.1016/j.soilbio.2015.01.009

Martins, A.P., Denardin, L.G. de O., Borin, J.B.M., Carlos, F.S., Barros, T., Ozorio, D.V.B., Carmona, F. de C., Anghinoni, I., Camargo, F.A. de O., Carvalho, P.C. de F., 2017. Short-term Impacts on Soil-quality Assessment in Alternative Land Uses of Traditional Paddy Fields in Southern Brazil. L. Degrad. Dev. 28, 534-542. https://doi.org/10.1002/ldr.2640

Mcdaniel, M.D., Grandy, A.S., 2016. Soil microbial biomass and function are altered by 12 years of crop rotation. Soil 2, 583-599. https://doi.org/10.5194/soil-2-583-2016

Menezes, V.G., Mariot, C.H.P., Lopes, M.C.B., Silva, P.R.F. da, Teichmann, L.L., 2001. Semeadura direta de genotipos de arroz irrigado em sucessao a especies de cobertura de inverno. Pesqui. Agropecuaria Bras. 36, 1107-1115. https://doi.org/10.1590/S0100-204X2001000900004

Miguez, F.E., Bollero, G.A., 2005. Review of Corn Yield Response under Winter Cover Cropping Systems Using Meta-Analytic Methods. Crop Sci. 45, 2318. https://doi.org/10.2135/cropsci2005.0014

O'Connell, S., Shi, W., Grossman, J.M., Hoyt, G.D., Fager, K.L., Creamer, N.G., 2015. Short-term nitrogen mineralization from warm-season cover crops in organic farming systems. Plant Soil 396, 353-367. https://doi.org/10.1007/s11104-015-2594-2

O'Reilly, K.A., Lauzon, J.D., Vyn, R.J., Van Eerd, L.L., 2012. Nitrogen cycling, profit margins and sweet corn yield under fall cover crop systems. Can. J. Soil Sci. 92, 353-365. https://doi.org/10.4141/cjss2011-065

Signor, D., Cerri, C.E.P., Conant, R., 2013. N2O emissions due to nitrogen fertilizer applications in two regions of sugarcane cultivation in Brazil. Environ. Res. Lett. 8, 015013. https://doi.org/10.1088/17489326/8/1/015013

SOSBAI, 2018. Arroz Irrigado - Recomendacoes tecnicas da pesquisa para o Sul do Brasil, Sociedade Sul brasileira de arroz irrigado. Cachoerinha.

Sousa, R.O. de, Carlos, F.S., Silva, L.S. da, Scivittaro, W.B., Ribeiro, P.L., Lima, C.L.R. de, 2021. No-tillage for flooded rice in Brazilian subtropical paddy fields: history, challenges, advances and perspectives. Rev. Bras. Ciencia do Solo 45. https://doi.org/10.36783/18069657RBCS20210102

Stotzky, G., 1972. Activity, ecology, and population dynamics. Crit. Rev. Microbiol. 1, 59-137.

Tabatabai, M.., 1982. Soil Enzymes*. Methods Soil Anal. Part 2. Microbiol. Biochem. Prop. 9, 903-947. https://doi.org/10.1002/0471263397.env211

Tedesco, M., Gianello, C., Bissani, C., Bohnen, H., Volkwiess, S., 1995. Analises de solo, plantas e outros materiais, 2nd ed. Porto Alegre-RS, Brazil. 
Tenelli, S., de Oliveira Bordonal, R., Barbosa, L.C., Carvalho, J.L.N., 2019. Can reduced tillage sustain sugarcane yield and soil carbon if straw is removed? Bioenergy Res. 12, 764-777. https://doi.org/10.1007/s12155-019-09996-3

US Soil Taxonomy, 1999. Soil taxonomy: A basic system of soil classification for making and interpreting soil surveys., 2nd ed. Washington.
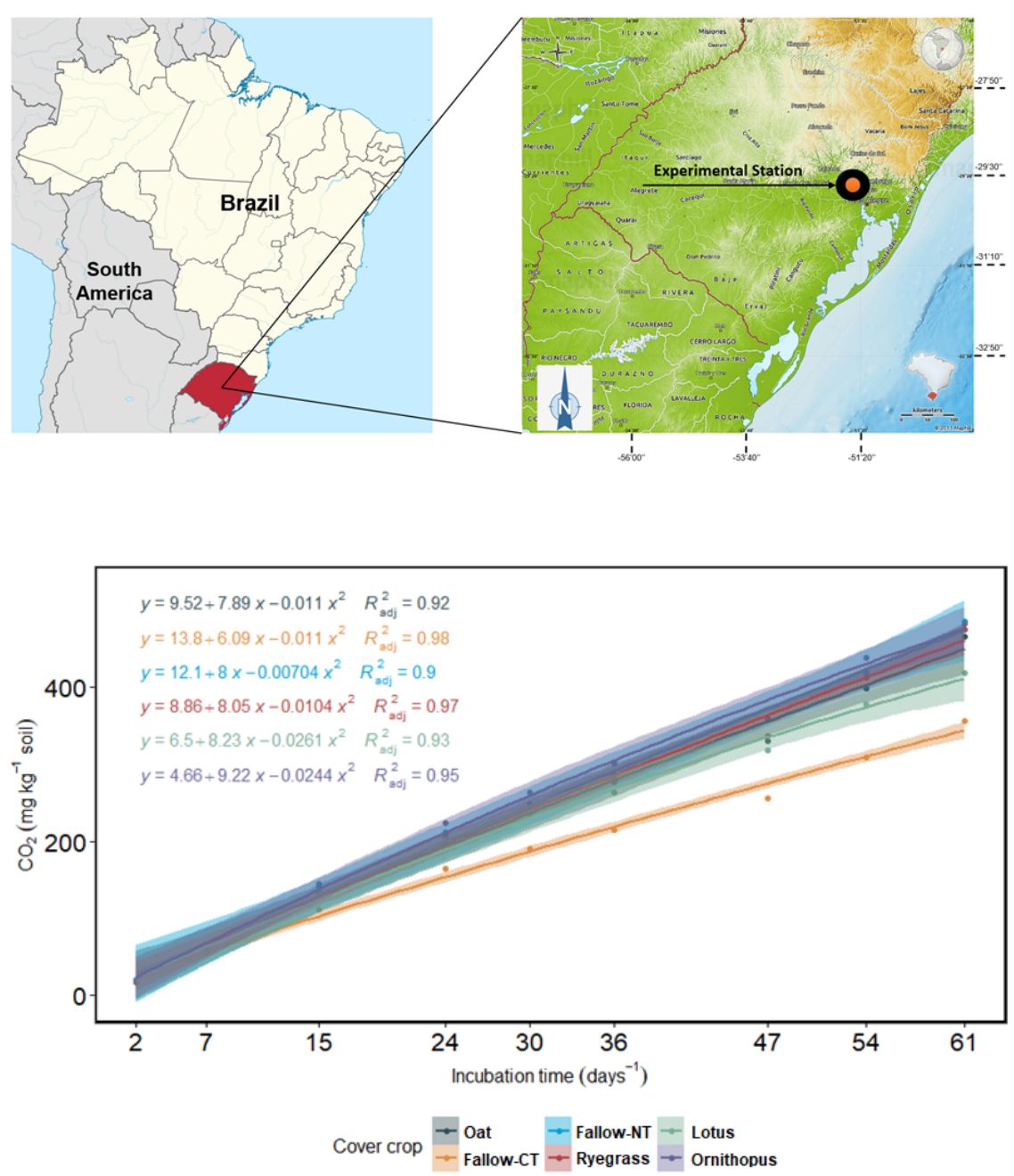

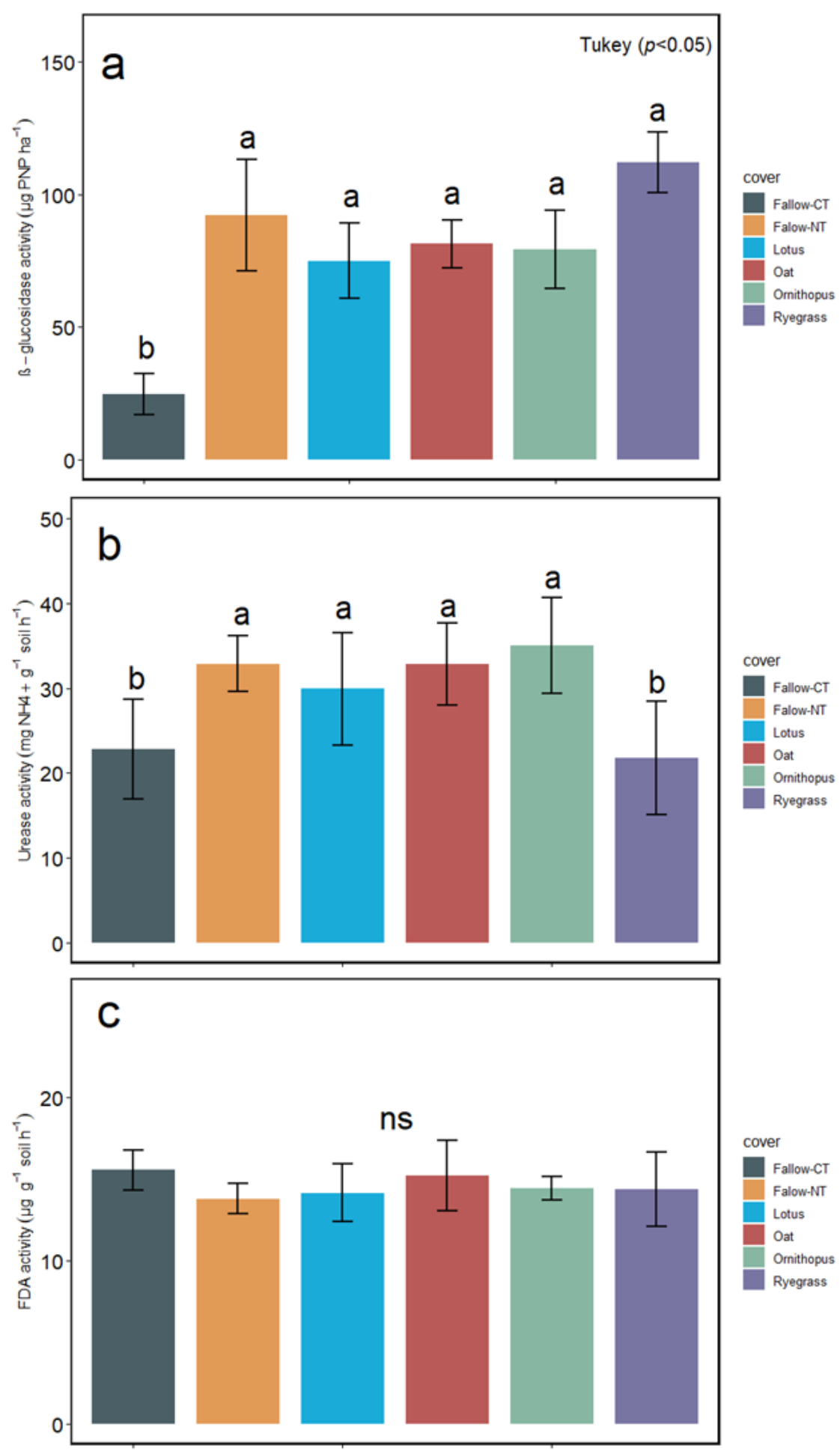


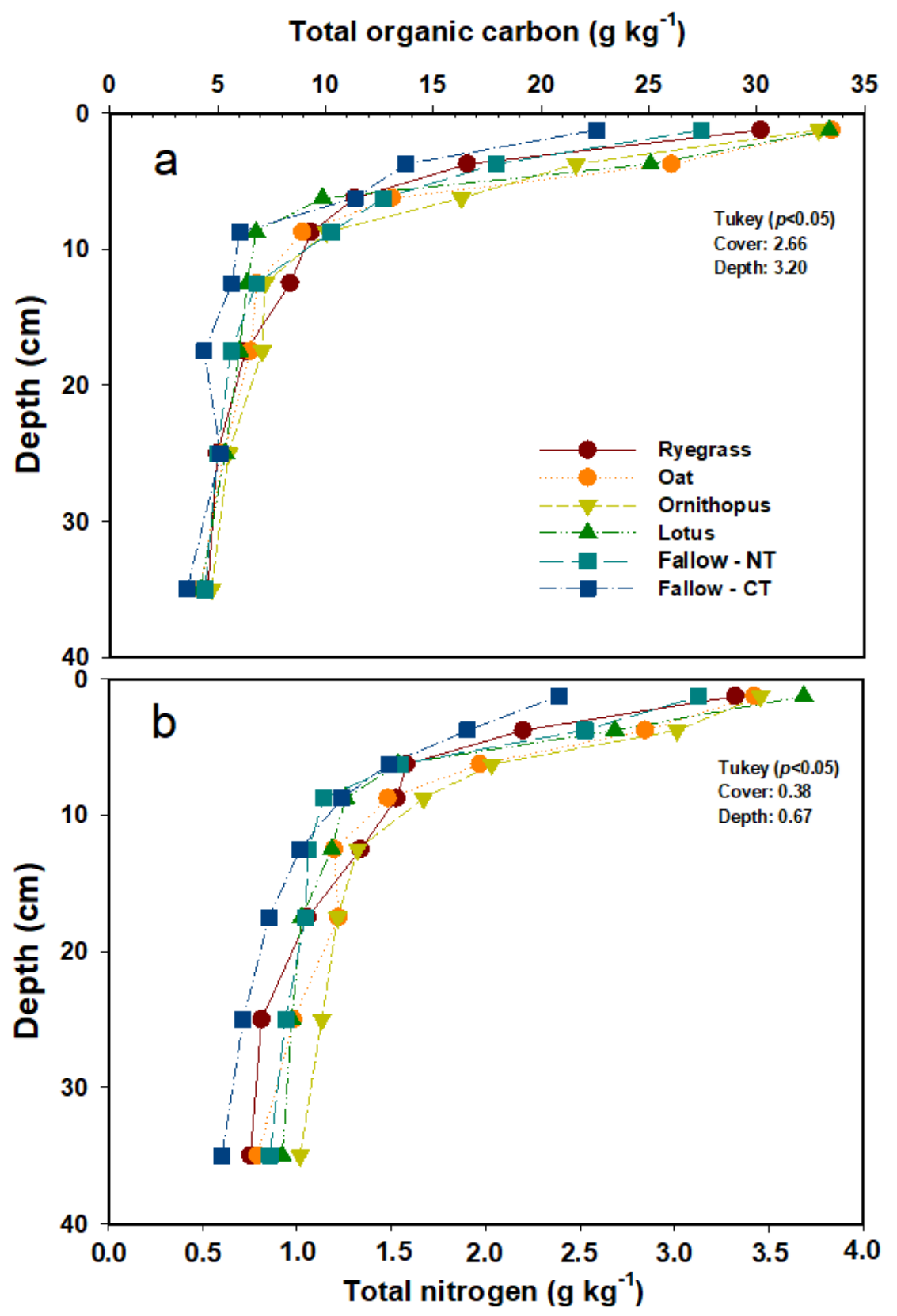




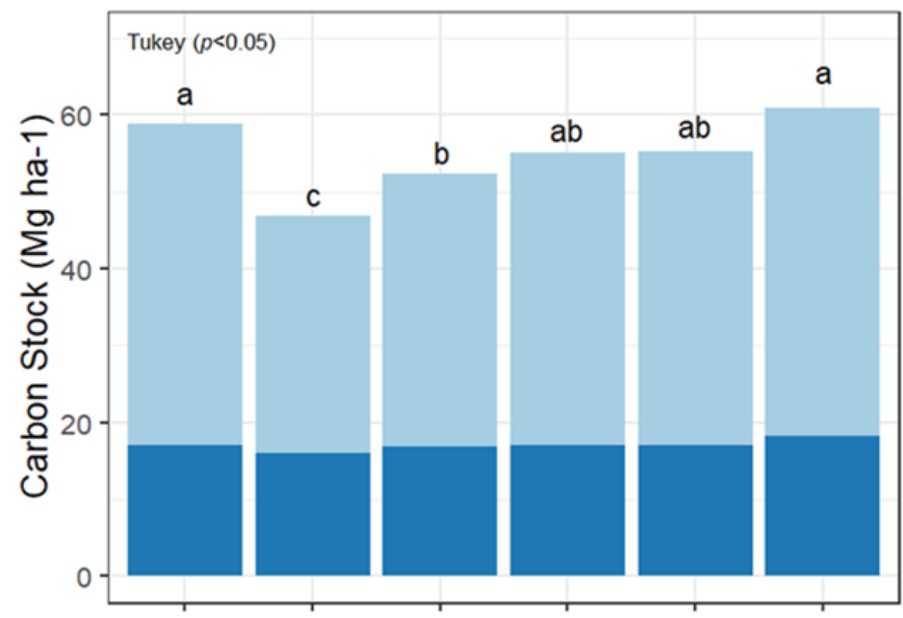

Layer
$0-20 \mathrm{~cm}$
$20-40 \mathrm{~cm}$

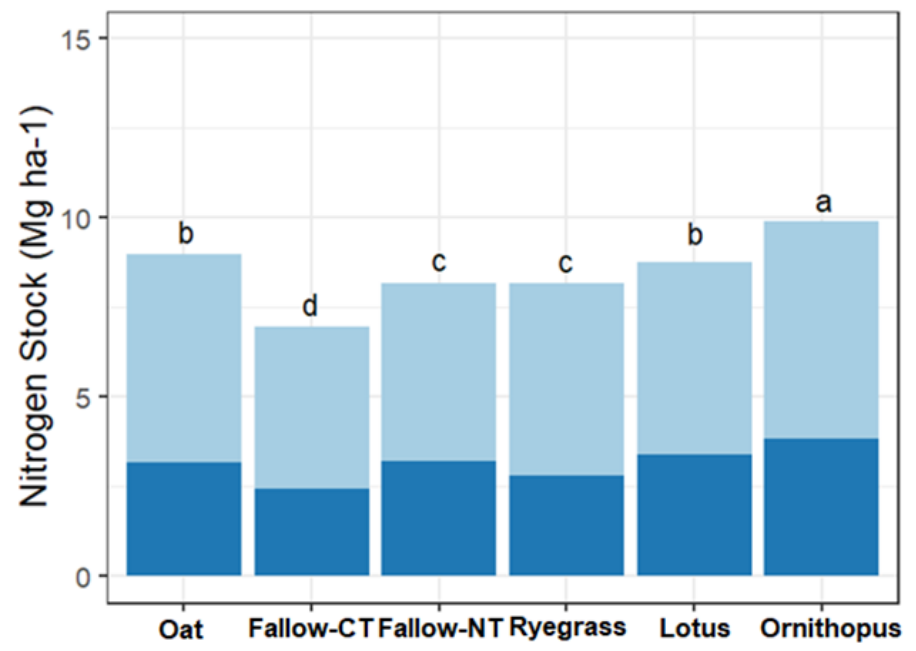

Layer

$0-20 \mathrm{~cm}$

$20-40 \mathrm{~cm}$ 

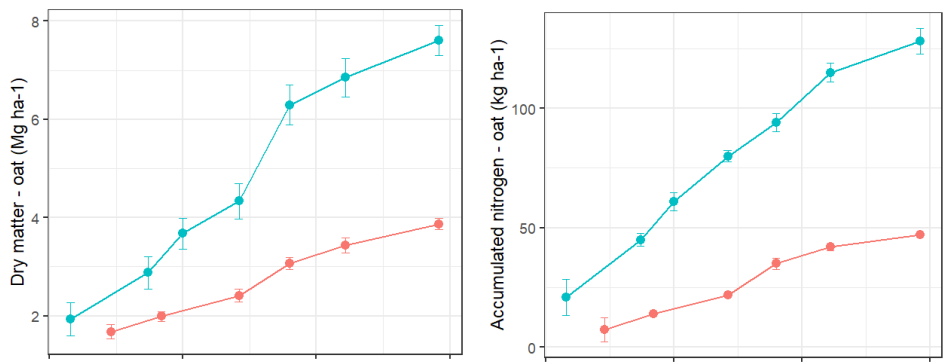

fert

- ConvFertilization
- SystemFertilization
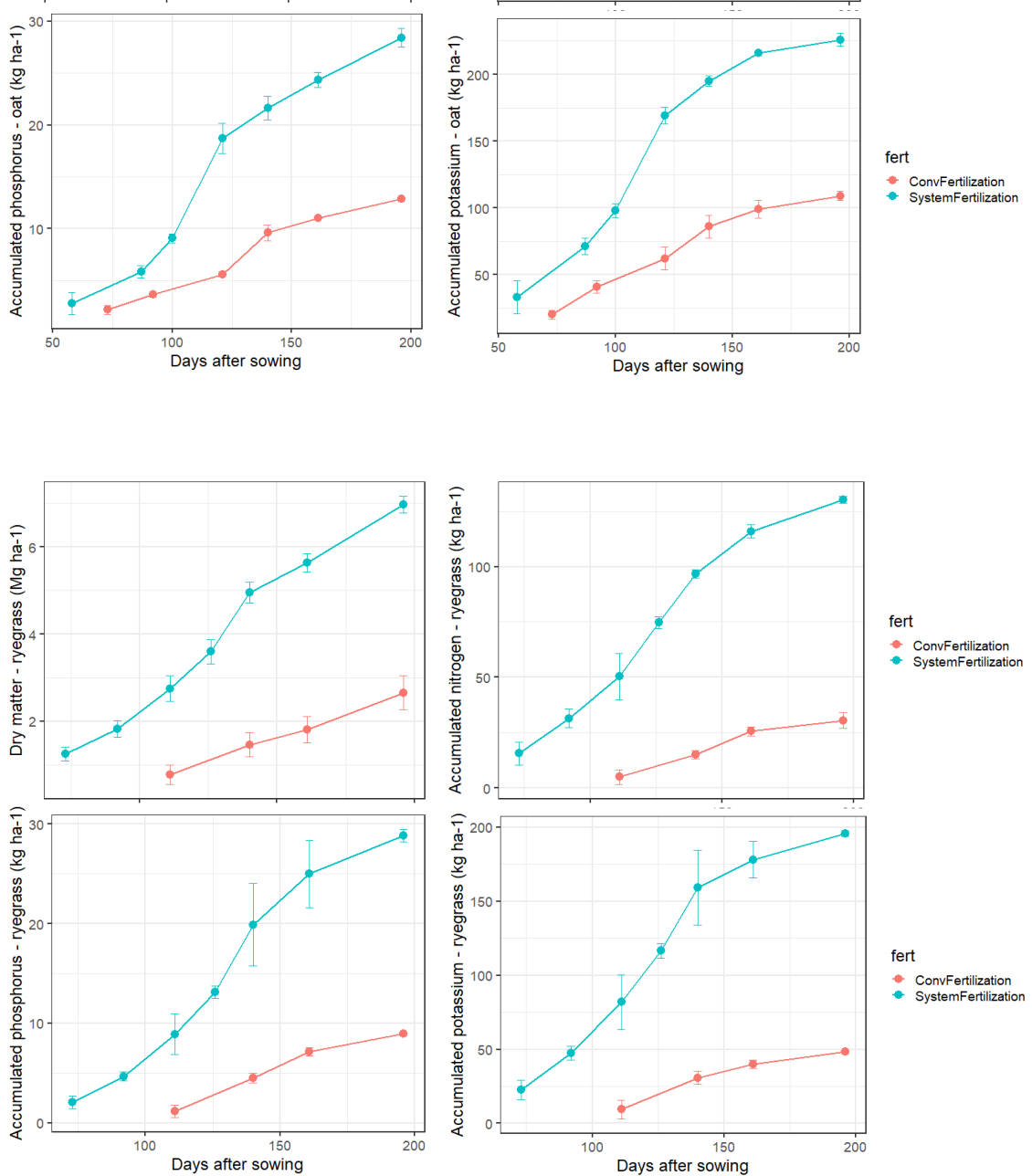

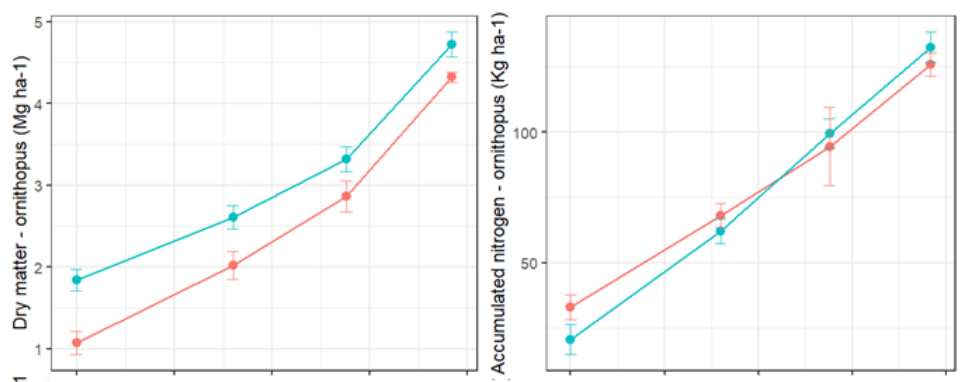

fert

- Convertilization
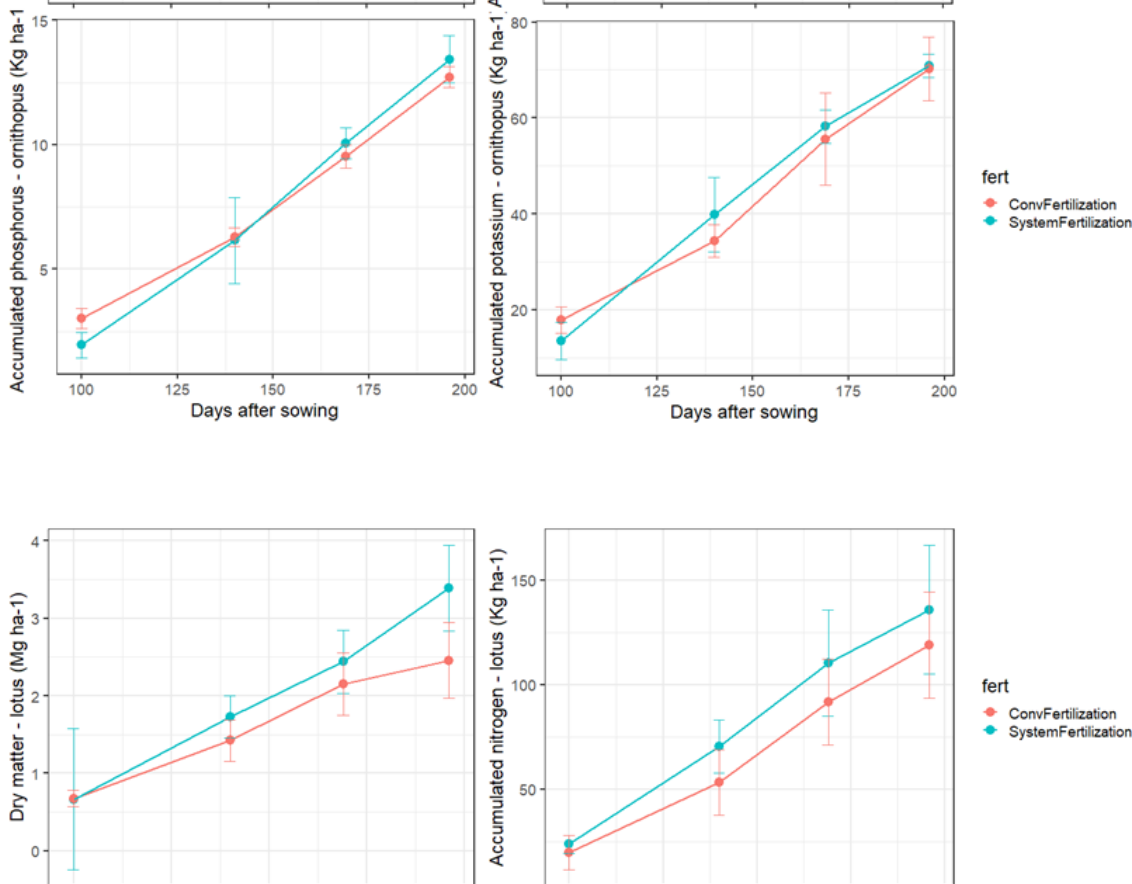

fert

- Converertizzation
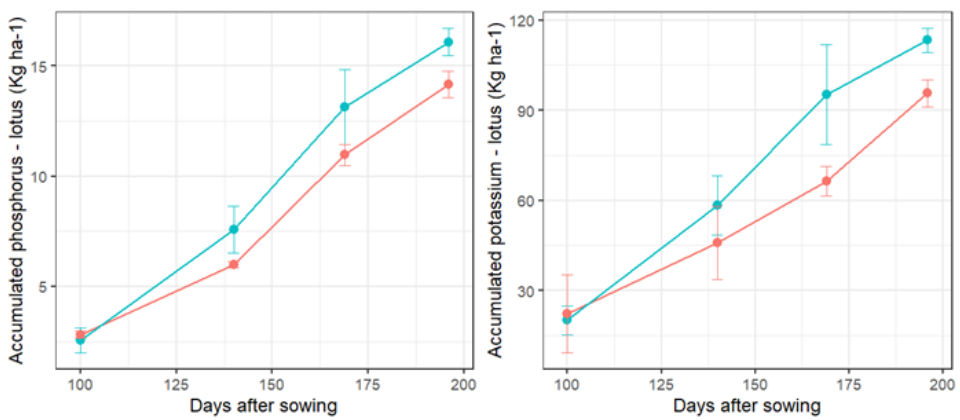

- Converetilization
Systemfertilization 

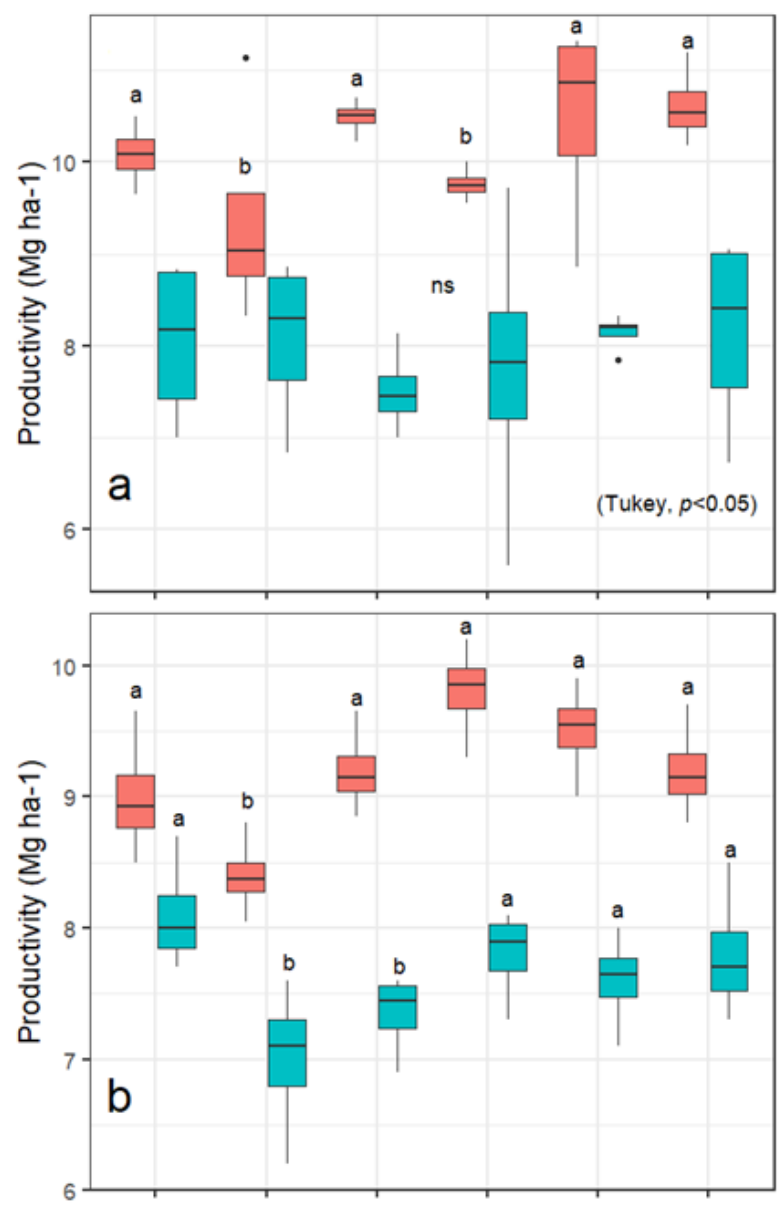

Crop season

2014/15

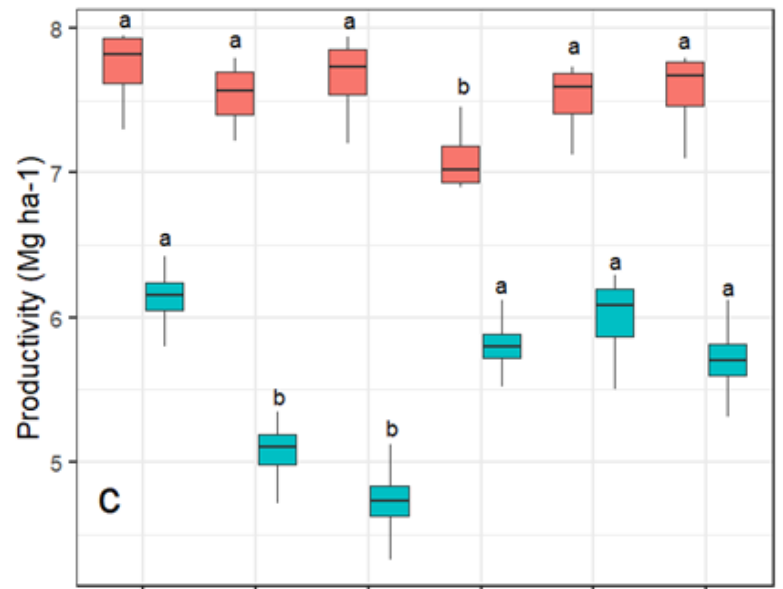

Crop season

2015/16

岸 Conventional fertilization

System fertilization

Oat Fallow-CT Fallow-NTRyegrass Lotus Ornithopus 


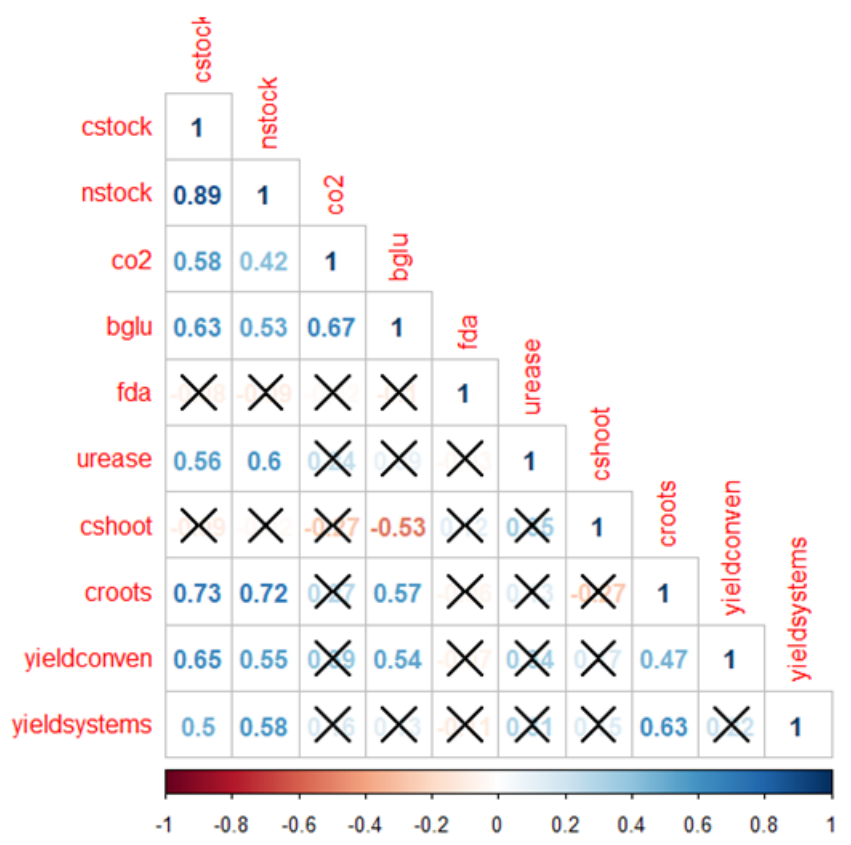




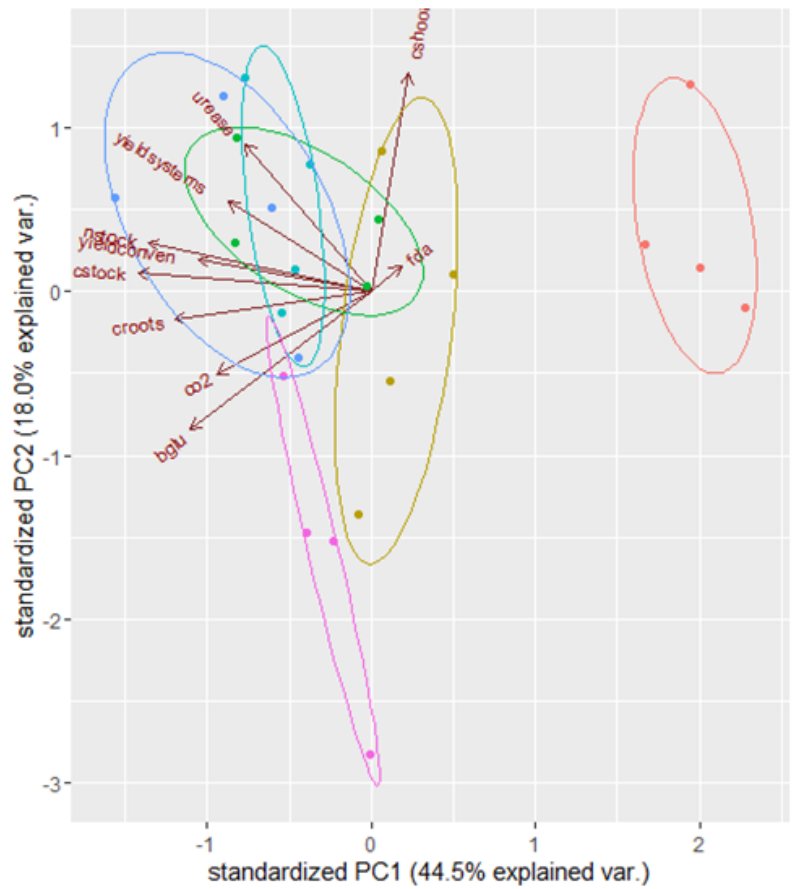
groups
- Fallow-CT
- Fallow-NT
- Lotus
- Oat
- Ornithopus
$\rightarrow$ Ryegrass

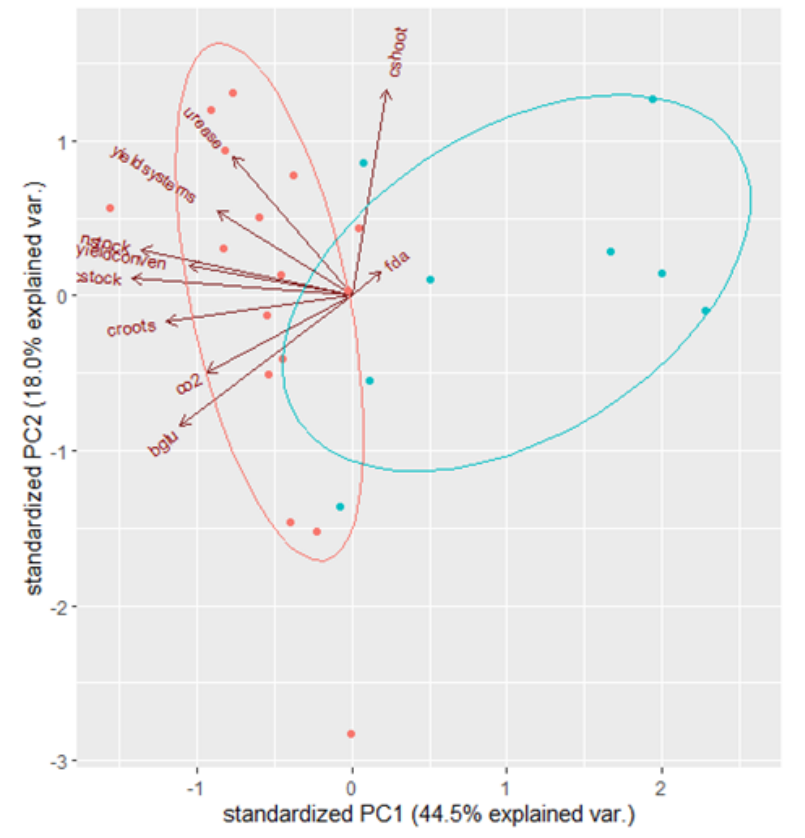

groups

- Cover crops

- Fallow 